\title{
A Study of The Impact of Financial Development on the Country's Monetization
}

\author{
Hao Liu ${ }^{1} \&$ Shijin Chen $^{2}$ \\ ${ }^{1}$ School of Statistics, Beijing Normal University of China, Beijing 100875, China \\ ${ }^{2}$ Finance and Economics College, Hebei Normal University of Science and Technology 066004, China \\ Correspondence: SHIJIN CHEN, Finance and Economics College, Hebei Normal University of Science and \\ Technology 066004, China.
}

Received: February 25, 2016

doi:10.11114/ijsss.v4i4.1446
Accepted: March 7, $2016 \quad$ Available online: March 10, 2016

URL: http://dx.doi.org/10.11114/ijsss.v4i4.1446

\begin{abstract}
Based on dynamic panel data from 45 countries, this article makes an empirical analysis of the determinants of M2/GDP ratio. It reveals that indirect financing dominated by banking system and direct financing dominated by financial markets jointly contribute to the rise of the M2/GDP ratio of a country, while the improvement of efficiency of banking industry and securities market helps reduce it. Finally it offers some suggestions on upgrading China's financial market and structure in terms of promoting its financial efficiency, innovation and reform.
\end{abstract}

Keywords: monetization; financial structure; determinant; empirical analysis

\section{Introduction}

Money plays an important role in modern economy. Economy in modern times, to some extent, is the economy of currency credit or economy of finance, which means that money supply and circulation guide the flow of resources in real economy. In other words, if the money economy runs normally and efficiently, the financing and investment in real economy will operate smooth. Accordingly, the allocation of social resources will be more reasonable, and the development of the economy will be sounder and be more balanced. In measuring the level of monetization of an economy, the ratio between M2 and GDP is usually employed. Take China for example. Since reform and opening up, China's M2 has increased rapidly, from 85.84 billion yuan in 1977 to 127.53 trillion yuan by the end of March, 2015, a rise of 1487 times, or an annual growth of $38 \%$ on average. The ratio between M2 and GDP also increased from $26.81 \%$ in 1977 to 1.93 in 2014 (see Figure 1 below), with the annual growth of M2 always higher than that of the GDP.

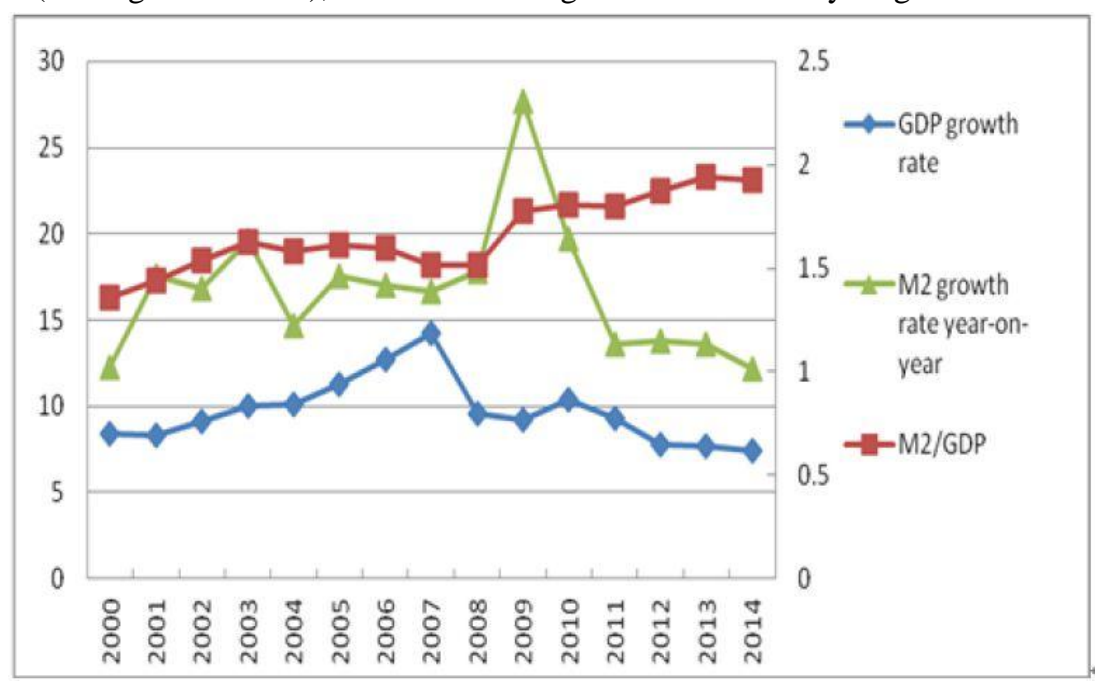

Figure 1. Changes of Monetization Rate, GDP Growth and M2 Growth in China since 2000 Sources: China statistical yearbooks; World Bank: the World Bank WDI Online 
Compared with other countries, China's M2/GDP ratios were not only higher than those of the major developed countries such as the United States, South Korea, the United Kingdom, but also much higher than those of the developing countries similar to China in terms of development level, such as India, Mexico, Brazil (see Figure 2).

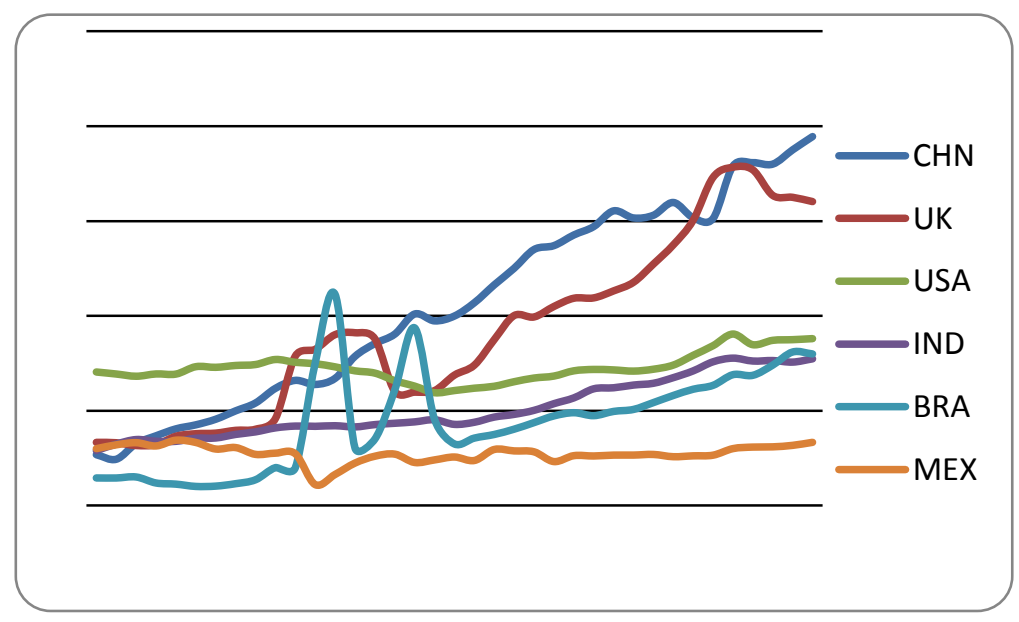

Figure 2. Changes of M2/GDP Ratio in China and Some Countries since 1977

\section{Source: Based on the World Bank-WDI Online}

Great attention has always been paid by scholars on following questions: What are the determining factors behind the monetization level of a country? What is the reasonable amount of money supplied? Is there any appropriate of range of it? And in the case of China, what is the trend of its future monetization level?

As can be seen in figure 1, the change in China's annual GDP growth rates corresponded closely with those of its M2. This indicates that the development of China's monetization is positively consistent with its economic growth. Nevertheless, some scholars are of the view that the issuance of currency is excessive in China and therefore express their concern over the potential risk of asset price bubble and inflation. But there are no widely accepted criteria in the world for judging the reasonable range of monetization level of an economy. To objectively explain the differences of the monetization level between economies, many factors should be taken into consideration, including stage of economic development, financial and industrial structures, opening level of the economy. In this paper, based on multi-national panel data, we try to make an empirical analysis of the influence of the financial structure of an economy on its monetization level from the perspective of financial structure; and the trend of the M2/GDP ratio in China in particular. On this basis, we also offer some operational suggestions on China's monetary policy, reform in financial structure and the role of financial system in promoting the upgrading of its real economy.

\section{Literature Review}

In the study of monetization rate, internationally speaking, scholars mainly focus on two issues. One is the trend of a country and the range where a turning point usually appear. For example, American economist Goldsmith (1969) believes that, during the economic development of a country, the growth rates indicated by financial structure are faster than that of its GDP, which is specifically manifested in the fact that the overall level of monetization shows a tendency of rising but its ratio are not unlimited. He thus put forward the hypothesis that, the path of monetization of a country follows a U-shaped curve. According to this hypothesis, the long-term trend of M2/GDP ratio follows an increasestable-decrease path. So there are turning points in it. Friedman and Schwartz (1982), through empirical analyses, demonstrated that the turning point of monetization level in Western countries was around 0.9. McKinnon (1973) expounded the optimal conditions for monetization. He argued that, the crucial factor for raising the level of monetization of a country is to increase and maintain the actual benefits of money held (by collecting seignior age and inflation tax). In developing countries, the ratio of monetization will keep rising but not in an unlimited manner. It will come to a point when the cost of money supply of the banking system controlled by the government offsets the benefits from currency expansion. After that, the M2/GDP ratio will remain stable. The Upper limit of currency expansion is believed to be around 1 to 1.2 .

Another issue focused by scholars is the influence of the ratio of monetization on economy. For example, Shaw (1973) made a comparative analysis of internal and external financing of corporations. He argued that monetary authorities should change the model from mainly relying on internal financing to increasing the supply of money and therefore the actual benefits of it, that is, to significantly increase the M2/GDP ratio. According to the theories of market transactions 
of Field (1984) and Friedman (1988), the increase of trading volume in securities market will lead to higher demand for money transaction, meaning the obvious positive correlation between trading volume in the securities market and money demand. Therefore, M2/GDP ratio of a country will naturally increase with the development of the capital market. Allen and Gale (2000) comparatively analyzed the capital dominated financial system and banking dominated financial system and came to the conclusion that, the two systems are complementary rather than substitutive to each other; constant improvement of financial structure plays a significant role in monetization and economic growth. Levine (1996; 2004) empirically analyzed the contribution of financial intermediaries and stock markets to economic growth and monetization by using multi-national panel data. He concluded that, in a country with higher income, the securities market is usually more efficient than the banking system; therefore, the development path of the financial system is the transformation from a banking dominated system to a market dominated one.

Focuses of existing studies on monetization rate by Chinese scholars are mainly as follows: Factors influencing M2/GDP ratio; the dynamic changes of M2/GDP ratios; the appropriate range of M2/GDP ratios and their relationship with inflation; the potential financial risk of China's high M2/GDP ratio. These studies are basically carried out from three perspectives. First, the perspective of demand for money. Xie Ping (1992) is one of the earliest who made an empirical analysis of the structure of China's financial assets. He believed that the high proportion of M2 in China's financial assets is associated with the heavy dependence of its economic growth on bank loan. By examining the financial structures of corporations, individuals and state-owned banks, he concluded that the transaction demand for physical commodity and financial assets led to the rise of M2/GDP ratio. By examining China's financial assets from 1978 to 1995 and making international comparisons, Yi Gang (1996)found that, the main factor responsible for the rise of monetization rate in China is the fact that, during the transitory period of reform and opening up, the change of the structure led to an unprecedented demand for money. He therefore argued that, China should increase its proportion of direct financing and make reform in its financial assets. Liu Mingzhi (2001) and Yu Yongding (2002) argued that China's high M2/GDP ratio come from its underdeveloped capital market. Zhao Liuyan and Wang Yiming(2005), by comparing the demand for money between agricultural and non-agricultural sectors, came to the conclusion that it was the change of industrial structure, specifically, the rise of the proportion of non-agricultural sectors, that led to the excessive demand for money. Zhang Jie 2006) and Huang Guitian(2011) held that, financial inhibition such as control of interest rate and currency exchange rate led to the low cost of holding money and therefore the increased demand for money.

Second, from the perspective of decline of velocity of money. After empirically analyzing factors affecting China's M2/GDP rate, Yu Yongding (2002) and Li Bin (2004) concluded that the excessively high M2/GDP ratios in China come from the underdevelopment of its financial market, the constant heavy savings rates, the drastic reduce of broad money and the heavy debt burden of the government. Liu Mingzhi(2001), Yi Gang(2003), Xie Ping and Zhang Huaiqing(2007) attribute China's high M2/GDP rates to its financial structure and high percentage of non-performing loans. Based on IS-LAM model, the analysis of Wu Jianjun (2007) arrives at the conclusion that institutional factors of income distribution, investment and finance are responsible for China's high M2/GDP ratio.

Third, from the perspective of relationship between M2/GDP ratio and prices and potential financial risk. Jiang Chun (2004) believes that excessively high M2/GDP ratios may bring about inflation and financial risk, but Qin Duo (2002) and Han Ping (2005) think otherwise. There are scholars, including Han Ping, Li Bin and Cui(2005) who hold that China's M2/GDP ratios show a logistic curve, that is, increases first, then slows down, and finally remain stable; they also estimate that the upper limit of the M2/GDP ratio and its turning point appear between 2.4-3.4.

From review above we can see that, there is few, if any, research touching on subject by using multinational data. This paper is an effort of the author to fill this gap by using multinational panel data, which has resulted in some new findings.

\section{Econometric Model and Empirical Analysis}

\subsection{Data Description}

Our samples are collected from 45 countries, including developed countries in OECD and developing countries in APEC. ${ }^{1}$ Our data are mainly from World Bank-WDI online, Global Financial Development Database and IMF International Financial Statistics, with a time span from 1996-2011. GDP data are from World Bank database of

\footnotetext{
${ }^{1}$ Samples are from the following countries : Australia, Austria, Belgium, Canada, Czech Republic, Denmark, Finland, France, Germany, Greece, Hungary, Iceland, Ireland, Italy, Japan, Korea, Luxembourg, the Netherlands, New Zealand, Norway, Poland, Portugal, Spain, Sweden, Switzerland, the United Kingdom, the United States, Israel, Slovakia, Slovenia, Estonia, Turkey, Singapore, Mexico, Argentina, Brazil, India, South Africa, Russia, China, the Philippines, Malaysia, Thailand, India, Indonesia, and Peru.
} 
National Economic Accounting (in domestic currency at current price), while their money supplies are based on the broad money M2 in IMF International Financial Statistics. The activity of securities market, represented by Str, is based on the turnover rates published by World Bank; The variable of the sizes of commercial banks, represented by bas, i.e., ratio between assets of deposit money bank and GDP, are based on data from IMF International Financial Statistics; CPIs are based on the same data source (annual inflation rate); the index of industrial structure (isb), based on data from The World Bank-WDI Online, is calculated through dividing the percentage of industrial added value in GDP by added value of services and others. Other controlled variables include: Gross national income( $\mathrm{gni}$ ), based on data from World Bank database of National Economic Accounting and OECD database of National Economic Accounting; The savings rates (sav) are the proportions of the gross savings to GDP, whose data is also based on same two data sources of World Bank and OECD. The opening level of economy is represented by tra, the proportion of total value of imports and exports of goods and services to GDP , based on data from World Bank database of National Economic Accounting; as is the data used to calculated the general government final consumption expenditure, represented by gov; real interest rates $(r r)$ are gained by interest rates on loans adjusted according to GDP deflators, based on data from IMF International Financial Statistics, with the rates data unprocessed. The data of economic volume have been processed by natural logarithm to eliminate heteroscedastic and dimensional disturbances. For a description of statistical results of the data, see Table 1.

Table 1. Statistical Description of the Main Data (1996-2011)

\begin{tabular}{cccccc}
\hline Variables & Observed value & Means & Standard deviation & Minimum & Maximum \\
\hline M2/GDP & 681 & 0.991898 & 0.847774 & 0.177954 & 6.698804 \\
gov & 717 & 18.70753 & 7.873374 & 0.913524 & 58.71816 \\
gni & 710 & 22436.55 & 18100 & 410 & 89000 \\
cpi & 720 & 4.831912 & 8.608417 & -4.47994 & 85.74178 \\
bas & 686 & 94.15309 & 50.50048 & 16.78391 & 275.2592 \\
str & 717 & 76.12658 & 58.77492 & 0.13917 & 393.3018 \\
tci & 720 & 23.0928 & 5.486053 & 9.873714 & 48.26513 \\
tra & 720 & 90.70279 & 66.53747 & 14.93285 & 439.6567 \\
sav & 712 & 24.03658 & 8.645153 & 0.010745 & 60.30717 \\
\hline
\end{tabular}

Data source: World Bank-WDI online

\subsection{Model Design and Empirical Analysis}

From the analysis above we can see that, macro-economic factors influencing the $\mathrm{M} / \mathrm{G}$ ratio of a country include: financial structure or size of banking system; development of financial market; development of secondary and tertiary industries; CPI, and national income. So the design of the econometric model is

$$
m_{\mathrm{i}, t}=\partial_{\mathrm{i}}+\beta_{m_{i, t-1}}+\alpha \times \text { bas }_{i, t}+\gamma \times \operatorname{str}_{i, t}+\eta \times C P I_{i, t}+\mu \times I S B_{i, t}+\theta \times X_{i t}+\mathcal{E}_{i, t}
$$

In this equation, $m$ is M2/GDP ratio, as a dependent variable. Given the fact that different money policies in a certain period of time are closely related to each other and have accumulative effects, we introduce a lag item as an explaining variable on the right side of the equation, representing the effect of policies of previous stage on those in the next stage; other explaining variables include bas, representing the size of commercial banks (assets of deposit money banks divided by GDP; Str is the degree of activity of the securities market, or the turnover rate; CPI, or consumer price index; $I s b$ is the industrial structure, gained through dividing the gross output value of secondary industry by that of tertiary industry; $\mathrm{X}$ represents various controlled variables; $\partial_{\mathrm{i}}$ is the individual effect of the countries; is the random disturbance term.

In this paper, we take the lag term of variables as the explaining variable, so the econometric model is one of dynamic panel data nature. The estimation of random effect, mixed OLS and fixed effects are all biased, which is insufficient to prove the hypothesis that the lag dependent variable as the explaining variable is not associated with error term. To solve this endogenous problem in dynamic panel data, we apply the estimation method of systematic GMM proposed by Blundell and Bond (1998) and Baum (2006), to combine the difference GMM and level GMM as one system. Since there is one lag length in the model, the most accurate method is to use dynamic panel data, and compare it with other methods, such as mixed OLS, fixed effect model as well as BCLSDV. In the model of M/G ratio, the indicator of it $(m)$ should have strong positive correlation with the next stage $\mathrm{M} / \mathrm{G}$ rate, that is, the coefficient $\beta$ should be positive. Because the deposit money bank as the primary financial agent holds the tasks of money multiplier expansion and 
money supply, their sizes are assumed to have a strong positive correlation with $\mathrm{M} / \mathrm{G}$ rate. That means, the stronger the financial system dominated by its indirect financing banks in a country, the more its money supply, and therefore, the coefficient $\alpha$ should be positive.

According to Field(1984) and Friedman(1988), securities market can exercise influence on the demand for money through transaction effect, portfolio effect and wealth effect, and the volume of transaction of the securities market has significant positive correlation with demand for money; so does the turnover rate of transaction in domestic stock market with the M2/GDP ratio, indicating that, the larger the amount of direct financing in the stock market, the more the money as the medium of transaction is demanded, therefore, $\gamma$ should be positive. The current CPI should have a positive correlation with current M2/GDP ratio. From the review in the second review of this article we can see that, in terms of industrial structure, the higher the proportion of tertiary industry in an economy, the bigger its demand for money, thus, the correlation between the isb mand M2/GDP ratio should be negative.

The coefficient of real interest rate ( $r r$ ) should be negative, because based on the hypothesis of Mckinnon (1973), the higher the real interest rate, the bigger the demand for money.

The estimated result of the model is as follows (figures in the brackets below the coefficients are $t$ values):

$$
\begin{aligned}
& m=-0.0202+0.908 l . m+0.105 b a s+0.0285 s t r-0.0158 i s b+0.0002 c p i+0.000598 \mathrm{rr} \\
& \begin{array}{lllllll}
(-0.48) & (-59.33) & (-11.09) & (-8.17) & (-2.53) & (-0.07) & (-2.87)
\end{array}
\end{aligned}
$$

Its comparisons with that of other methods are shown in Table 2. From the coefficient of the L.m into which an explaining variable is added (figures in the next lines) we can see that, in the estimation of systematic GMM, the coefficient is 0.908 , which is higher than that of fixed effect $(0.77)$ and lower than that of mixed OLS(0.918), and also higher than those of the BCLSDV and difference GMM. This means that, it is in accordance with the theoretical prediction and falls within the typical range of the theoretical analysis; the value of the coefficients are all greater than zero, and significant in the confidence level of $1 \%$. Moreover, the $\mathrm{P}$ value of the second order correlation test in the estimation of the systematic GMM is 0.791 , bigger than 0.1 , which accords with the original hypothesis that if the second order autocorrelation coefficient of the difference of the disturbance term is zero, there is no second order correlation. The endogenous problem thus is properly solved. The Chi-square value in Sargan is 30.694, showing that all instrumental variables in the original hypothesis are effective and it's selections are reasonable.

From this we can initially conclude that, every one percentage rise of the indicator of bank size (bas), the M/G ratio will rise $10.5 \%$, meaning that the indirect financing system dominated by banks will make the M2/GDP ratio rise remarkably. Every one percentage rise of indicator of the securities market (str), the indicator of M2/GDP ratio will rise $2.85 \%$. This implies that the development of capital market dominated by direct financing will also increase the demand for money transaction. The estimated coefficient of industrial structure indicator (is $b$ ) is -0.0158 , suggesting that, with the rise of the proportion of tertiary industry in GDP, the efficiency of money will increase, which will reduce the demand for money and M2/GDP ratio accordingly. The estimated coefficient of the real interest rate is 0.000598 , which is in accordance with our theoretical analysis, that is, the higher the real interest rate, the lower the actual utilization efficiency of the money, so that the pricing and allocating functions of the market are underperformed, resulting in greater dependence upon money supply.

Table 2. Comparisons among coefficients from different estimation method

\begin{tabular}{cccccc}
\hline $\begin{array}{c}\text { Explaining } \\
\text { variables }\end{array}$ & Mixed OLS & Fixed effect & Systematic GMM & $\begin{array}{c}\text { Difference } \\
\text { GMM }\end{array}$ & BCLSDV \\
\hline L.m & $0.918^{* * *}$ & $0.770^{* * *}$ & $0.908^{* * *}$ & $0.845^{* * *}$ & $0.867^{* * * *}$ \\
& $(-35.22)$ & $(-11.37)$ & $(-59.33)$ & $(-28.25)$ & $(-30)$ \\
Bas & $0.0961^{* * *}$ & $0.144^{* * *}$ & $0.105^{* * *}$ & $0.115^{* * *}$ & $0.111^{* * *}$ \\
& $(-4.17)$ & $(-3.55)$ & $(-11.09)$ & $(-5.51)$ & $(-5.28)$ \\
Str & $0.0255^{* *}$ & $0.0324^{* * *}$ & $0.0285^{* * *}$ & $0.0310^{* *}$ & $0.0303^{* *}$ \\
& $(-2.91)$ & $(-3.81)$ & $(-8.17)$ & $(-2.99)$ & $(-2.8)$ \\
Isb & 0.0117 & $-0.252^{*}$ & -0.0158 & $-0.197^{*}$ & $-0.183^{*}$ \\
& $(-0.85)$ & $(-2.63)$ & $(-1.04)$ & $(-2.53)$ & $(-2.34)$ \\
Cpi & -0.000375 & -0.000103 & 0.00016 & -0.0000534 & 0.00000354 \\
& $(-1.12)$ & $(-0.33)$ & -1.91 & $(-0.07)$ & $(0)$ \\
Rr & 0.000132 & -0.000434 & $0.000598^{* *}$ & 0.000123 & 0.000444 \\
& $(-0.63)$ & $(-0.56)$ & $(-2.87)$ & $(-0.14)$ & $(-0.51)$ \\
Absolute & $(-1.07)$ & $(-2.92)$ & $(-0.48)$ & & 463 \\
terms & 463 & 463 & 456 & 463 & \\
Samples & & & & \\
\hline
\end{tabular}

Note: $* * *, * *, *$ represents $1 \%, 10 \%$ and $5 \%$ significance level respectively, and figures in the brackets are $\mathrm{t}$ value. 


\subsection{Robustness Test of the Model}

The estimation of the benchmark model supports the hypothesis that the development of financial system, through channels such as commercial banks and securities markets increases the M2/GDP ratio to meet the growing demand of real economy for money. This conclusion, however, may be influenced by various heterogeneous factors, including levels of national incomes, economic cycles, development stages, and openness of trade. So it is necessary to add more controlled variables into the model, and to test the robustness of the conclusion from different time spans.

First, we add into it variables of national incomes, savings rates and openness of the economy. The results of the estimation show that, the coefficients of bas and str are still significant and positive (See figures in line 2, 3, and 4 of Table 3). To further test its robustness, we change the key explaining variable by replacing the variable of capital market scale $(s t r)$ with the private credit scale $(p c b)$ of the deposit banks and the proportion of volume of the stock market to GDP(svt). The results show statistical significance both in banking system and securities factors (See column 5 and 6 in Table 3).

In terms of years, the coefficients of influence of the commercial bank system and securities market on M2/GDP ratios are 0.317 and 0.042 respectively, which are apparently higher than those prior to 2008, (0.091 and 0.022$)$ and statistically significant(See column 3, 7 and 8 in Table 3). This indicates that, various measures and polices, including $\mathrm{QE}$, taken by countries since the global financial crisis have pushed up the M2/GDP ratio.

Generally speaking, the development of financial system, either indirect financing dominated by banking system or direct financing dominated by capital market, has a positive influence on M2/GDP ratio, or has promoted the expansion of amount of money. It tallies well with the model and hypothesis in our analysis. There is no second order series correlation in the difference of disturbance term in the estimation results (See the 2nd line from the bottom in Table 3 ). The Chi-square value of Sargan test demonstrates the hypothesis (See bottom line in Table 3), indicating that the selection of the instrumental variable is reasonable. The robustness of the all results is proved by the testability of all models.

Table 3. Comparisons among robustness of estimation results of different kinds

\begin{tabular}{|c|c|c|c|c|c|c|c|}
\hline Variables & $\begin{array}{c}\text { National } \\
\text { income }\end{array}$ & $\begin{array}{l}\text { Savings } \\
\text { rate }\end{array}$ & openness & PCB & $\begin{array}{c}\text { Volume } \\
\text { of stock } \\
\text { market }\end{array}$ & $\begin{array}{c}\text { Before } \\
2008\end{array}$ & $\begin{array}{l}\text { After } \\
2008\end{array}$ \\
\hline L.m & $\begin{array}{l}0.908^{* * * *} \\
(-59.33)\end{array}$ & $\begin{array}{c}0.950^{* * * *} \\
(-188.05)\end{array}$ & $\begin{array}{l}0.918^{* * * *} \\
(-49.72)\end{array}$ & $\begin{array}{l}0.944^{* * *} \\
(-58.39)\end{array}$ & $\begin{array}{l}0.914^{* * * *} \\
(-50.72)\end{array}$ & $\begin{array}{l}0.922^{* * * *} \\
(-43.02)\end{array}$ & $\begin{array}{l}0.753^{* * *} \\
(-13.14)\end{array}$ \\
\hline $\mathrm{Rr}$ & $\begin{array}{c}0.0006^{* * *} \\
(-2.87)\end{array}$ & & $\begin{array}{c}0.00078^{* * * *} \\
(-4.77)\end{array}$ & $\begin{array}{c}0.00091^{* * * *} \\
(-8.64)\end{array}$ & $\begin{array}{c}0.00074^{* * * *} \\
(-3.58)\end{array}$ & $\begin{array}{c}-5.1 \mathrm{E}-05 \\
(-0.26)\end{array}$ & $\begin{array}{c}0.0033^{* * * * *} \\
(-3.83)\end{array}$ \\
\hline Bas & $\begin{array}{l}0.105^{* * * * *} \\
(-11.09)\end{array}$ & $\begin{array}{c}0.0560^{* * * *} \\
(-10.59)\end{array}$ & $\begin{array}{c}0.0877^{* * * *} \\
(-4.89)\end{array}$ & & $\begin{array}{c}0.0915^{* * * *} \\
(-7.44)\end{array}$ & $\begin{array}{c}0.0909^{* * * * *} \\
(-5.53)\end{array}$ & $\begin{array}{l}0.317^{* * * *} \\
(-4.24)\end{array}$ \\
\hline Str & $\begin{array}{c}0.0285^{\text {**** }} \\
(-8.17)\end{array}$ & $\begin{array}{l}0.0330^{* * * *} \\
(-14.36)\end{array}$ & $\begin{array}{c}0.0388^{* * *} \\
(-4.18)\end{array}$ & $\begin{array}{c}0.0201^{* * *} \\
(-3.16)\end{array}$ & & $\begin{array}{c}0.0221^{* * *} \\
(-4.31)\end{array}$ & $\begin{array}{c}0.0421^{* * * *} \\
(-3.69)\end{array}$ \\
\hline Isb & $\begin{array}{c}-0.0158 \\
(-1.04)\end{array}$ & $\begin{array}{c}-0.0847^{*} \\
(-2.12)\end{array}$ & $\begin{array}{c}-0.0348^{* * * *} \\
(-3.95)\end{array}$ & $\begin{array}{c}-0.0388^{* * * *} \\
(-4.37)\end{array}$ & $\begin{array}{c}-0.0357^{* *} \\
(-3.23)\end{array}$ & $\begin{array}{c}-0.0626^{* * * *} \\
(-4.11)\end{array}$ & $\begin{array}{l}0.136^{*} \\
(-2.01)\end{array}$ \\
\hline Cpi & $\begin{array}{l}0.00016 \\
(-1.91)\end{array}$ & $\begin{array}{c}-0.00026 \\
(-1.29)\end{array}$ & $\begin{array}{c}0.000144 \\
(-1.23)\end{array}$ & $\begin{array}{c}0.000211^{*} \\
(-2.54)\end{array}$ & $\begin{array}{c}-4.2 \mathrm{E}-05 \\
(-0.58)\end{array}$ & $\begin{array}{c}0.000135 \\
(-1.19)\end{array}$ & $\begin{array}{c}-0.00404^{* * *} \\
(-2.60)\end{array}$ \\
\hline Lngni & $\begin{array}{c}0.002 \\
(-0.43)\end{array}$ & & & & & $\begin{array}{c}-0.00487 \\
(-1.66)\end{array}$ & $\begin{array}{c}-0.0231 \\
(-1.16)\end{array}$ \\
\hline Sav & & $\begin{array}{l}0.156^{* * *} \\
(-3.16)\end{array}$ & & & & & \\
\hline Tra & & & $\begin{array}{l}0.011 \\
(-0.8)\end{array}$ & & & & - \\
\hline Pcb & & & & $\begin{array}{c}0.0879^{* * * *} \\
(-6.23)\end{array}$ & & & \\
\hline Svt & & & & & $\begin{array}{c}0.0265^{* * * *} \\
(-3.44)\end{array}$ & & \\
\hline $\begin{array}{l}\text { Absolute } \\
\text { terms }\end{array}$ & $(-0.48)$ & $(-0.32)$ & $(-1.07)$ & $(-1.26)$ & $(-2.92)$ & $(-2)$ & $(-0.39)$ \\
\hline Samples & 456 & 553 & 463 & 463 & 463 & 397 & 59 \\
\hline $\operatorname{ar}(1)$ & 0.0164 & 0.011 & 0.0166 & 0.0165 & 0.0166 & 0.0289 & 0.0107 \\
\hline $\operatorname{ar}(2)$ & 0.791 & 0.6064 & 0.7978 & 0.7743 & 0.7164 & 0.8819 & 0.1904 \\
\hline Sargan & 30.69 & 37.42 & 32.44 & 36.17 & 34.68 & 30.26 & 15.41 \\
\hline
\end{tabular}

Note: $* * *, * *, *$ represents $1 \%, 10 \%$ and $5 \%$ significance level respectively; figures in the brackets are t values.

\subsection{An Extended Analysis of the Relationship between Financial Structure and Financial Efficiency}

As discussed above, the financial structure of a country can substantially influence its M2/GDP ratio. What then, within this context, are the mechanisms for and effects of the internal efficiency and structure of the commercial banks and 
securities markets to exercise their influence on its M2/GDP ratio? We can answer this question by conduct an extended analysis in two steps: First, we can examine whether there is a linear relations between the scale of banks and the M2/GDP ratio, represented by squared proportion of bank assets to GDP (bas2), and the cross effect of banking efficiency and scale on M2/GDP ratio, can be represented by bank's net interest margin(bnm); the bigger the margin, the lower the efficiency of the bank, which means that its lower creative capability for deposit money and unfavorable for M2 supply. The influence of availability of banking services on M2/GDP ratio is represented by the cross effects of number of bank branch per 100,000 persons and the scale of banking industry. The better the availability of banking service, the more efficient the utility rate of the money and turnover rate of capital, resulting the decline of demand for M2.

Second, we examine it from the perspective of securities market. The more efficient the securities market, the more complex its influence on demand for money, which potentially means that financing relies more on capital market rather than traditional commercial banks and eventually increase the demand for M2. We use stock market returns ( $s m r$ ) to represent its cross effect on turnover rate in securities market. The availability of securities market services is represented by the ratio between the total stock market value and GDP $(s m c)$, indicating the overall effect of the progress in scale and quality of the securities market for financing in capital market. The higher the quality of the securities market, the smaller the demand for M2. The results of empirical analysis of internal structure of financial system are shown in Table 4 below.

Table 4. Results of extended analysis of the relationship between financial structure and efficiency

\begin{tabular}{|c|c|c|c|c|c|}
\hline Variables & $\mathrm{Bas}^{2}$ & Banking efficiency & $\begin{array}{c}\text { Banking } \\
\text { availability }\end{array}$ & $\begin{array}{c}\text { Securities market } \\
\text { efficiency }\end{array}$ & Securities market \\
\hline \multirow[t]{2}{*}{ L1.m } & $0.909^{* * * *}$ & $0.955^{* * * *}$ & $0.912^{* * *}$ & $0.899^{* * * *}$ & $0.927^{* * * *}$ \\
\hline & $(32.708)$ & $(38.662)$ & $(76.061)$ & (55.667) & $(39.246)$ \\
\hline \multirow[t]{2}{*}{$\operatorname{Rr}$} & $0.001^{* * *}$ & $0.001^{* * *}$ & $0.001^{* * *}$ & 0 & $0.001^{* * *}$ \\
\hline & (2.997) & $(8.906)$ & $(3.813)$ & $(0.835)$ & $(2.511)$ \\
\hline \multirow[t]{2}{*}{ Str } & $0.033^{* * *}$ & $0.019^{* *}$ & $0.02^{* * *}$ & $0.038^{* * *}$ & $0.052^{* * *}$ \\
\hline & $(4.316)$ & $(2.233)$ & $(3.627)$ & (16.013) & $(4.974)$ \\
\hline \multirow[t]{2}{*}{ Isb } & $-0.028^{* * *}$ & $-0.04^{* * *}$ & $-0.033^{*}$ & 0.038 & $-0.046^{* * *}$ \\
\hline & $(-2.602)$ & $(-3.734)$ & $(-1.71)$ & $(1.485)$ & $(-6.11)$ \\
\hline \multirow[t]{2}{*}{ Bas } & $0.212^{* * * *}$ & $0.092^{* * * *}$ & $0.124^{* * *}$ & $0.128^{* * * *}$ & $0.094^{* * * *}$ \\
\hline & $(6.294)$ & $(4.985)$ & $(7.918)$ & $(5.152)$ & (4.348) \\
\hline \multirow[t]{2}{*}{ Absolute terms } & $-0.052^{* * *}$ & 0.001 & 0.013 & $-0.051^{* * *}$ & 0.005 \\
\hline & $(-3.262)$ & $(0.048)$ & $(0.971)$ & $(-2.912)$ & $(0.623)$ \\
\hline $\mathrm{Bas}^{2}$ & $\begin{array}{l}-0.045^{* * *} \\
(-4.544)\end{array}$ & & & & \\
\hline $\mathrm{Bnm}$ & & $\begin{array}{l}-0.006^{* * * *} \\
(-5.198)\end{array}$ & & & \\
\hline Bpa & & & $\begin{array}{l}-0.001^{* * *} \\
(-3.074)\end{array}$ & & \\
\hline Smr & & & & $\begin{array}{l}-0.0001^{* * * *} \\
(-25.632)\end{array}$ & \\
\hline Smc & & & & & $\begin{array}{l}-0.029^{* *} \\
(-2.568)\end{array}$ \\
\hline Samples & 463 & 399 & 206 & 399 & 463 \\
\hline $\mathrm{AR}(1)$ & 0.016 & 0.034 & 0.039 & 0.001 & 0.017 \\
\hline $\mathrm{AR}(2)$ & 0.802 & 0.928 & 0.12 & 0.356 & 0.919 \\
\hline chi2 & 33.4 & 31.25 & 29.9 & 28.43 & 33.18 \\
\hline
\end{tabular}

Note: $* * * * *, *$ represents $1 \%, 10 \%$ and $5 \%$ significance level respectively; figures in the brackets are $\mathrm{t}$ values.

What we can see from Table 4 are as follows:

(1) From column 2 we can see that, the relations between scale or size of banking system and M2/GDP ratio and money supply are not linear. This means that, the estimated coefficient $b_{a s}{ }^{2}$ is -0.045 , indicating that in the initial stage of expansion of the commercial bank has a significant influence on the increase of M2, demonstrated by the statistical significance of estimated coefficient bas 0.212 . The consequence of it is the decline of the bank's capability for money creation, showing an inverted U-shape curve.

(2) From column 3 we can see that, the coefficient of the cross effect of banking efficiency and bnm is -0.006 , indicating that the lower the banking efficiency, the poorer the satisfaction of market demand for money, or poorer 
liquidity in real economy.

(3)The estimated coefficient of cross effect of banking availability (bpa) is -0.001 , indicating that the better the banking service, the more conducive it is to the rise of M2/GDP ratio.

(4) The estimated coefficient of cross effect of efficiency of securities market $(s m r)$ is 0.0001 , showing that the better the efficiency of the securities market, the lesser the reliability on traditional banks and lower the M2/GDP ratio due to the more financing of the real economy in securities market.

(5) The estimated coefficient of cross effect of $s m c$ is -0.029 , showing a better services in securities market can reduce the overall demand for money.

(6) The absence of second order autocorrelation in the difference of disturbance term suggests that, the endogenous problem of the explaining variable has been solved, therefore the systematic GMM can be used. And the value of chi-square test for over identification test (Sargan test) is above $1 \%$, meaning no rejection of the hypothesis that all instrumental variables are effective, and the estimated conclusion of GMM is reliable.

\section{Conclusions and Policy Suggestions}

From the above analysis we can conclude that, the M2/GDP ratio of a country is closely associated with its financial structure; the demand for money of the real economy is mainly met through the financial intermediary and capital market; the development of financial system in an economy, either banking or capital market dominated, has a significantly positive correlation with its M2/GDP ratio. Specifically, our conclusions are as follows:

(1) In terms of the actual influence of the financial structure on M2/GDP ratio, the influence of the banking system is higher than the securities market. This indicates that, commercial banking system as the indirect financing channel plays a more significant role in the execution of monetary policy. It has a multiplier effect in monetary expansion. Therefore, financing and investment activities in the real economy can be substantial regulated through adjustment of money supply and credit, cash balance, excess deposit reserve, legal reserve requirement on deposit and reserve and balance sheet items. From the point of view of efficiency and availability of the banking system, the higher the efficiency and service quality, the more conducive it is to the reduction of M2/GDP ratio. So to reduce the excessive reliance on money supply in an economy, the overall efficiency and availability of its large commercial banks should be substantially improved

(2) From the empirical analysis of the capital market, we can see that the higher the turnover rate in the stock market, the more the money is demanded, which will increase the M2/GDP ratio. In terms of crossover effect of the securities market efficiency and service availability, however, a bigger financing scale and better service efficiency is more beneficial to financing and investment of the real economy in the capital market, thus reducing its reliance on indirect financing from the bank. Moreover, the direct financing in the capital market is a market based pattern of resource allocation, which is higher efficiency and beneficial to reducing demand for money. Generally speaking, in the initial stage of its development, the capital market meets mainly the demand for direct financing of various economic entities in their activities. With the development of economy, financial innovation and diversity of financial tools, in addition to meeting the economy's demand for money, various financial tools play also the functions of assets and store of value like money. So the influence of the securities market on M2/GDP ratio is the overlapping effects from the growing demand for money because of stock and securities transactions and from the substitution of banking facility. In the early stage of economic development, monetization proceeds financializaton, which will accelerate at a certain stage of the former, leading to the rapid increase of non-monetary financial tools and assets and the upgrading from indirect financing from the bank to direct financing in the capital market.

(3) Seeing from the influence of macro-economy on M2/GDP ratio, the industrial structure of an economy, the development of tertiary industry in particular, has a negative effect for M2/GDP ratio. It means that, the growth of service industry and its improvement can reduce the dependence of the growth on the secondary industry, which is characterized by large demand for money. As a result, the M2/GDP ratio will increase rapidly, as is the case in China. In terms of interest rates, high interest rates indicate the limited capability of the market in allocating financial resources and poor mechanism for market pricing, resulting in the low efficiency of money utility, the demand for money and eventually the rise of M2/GDP ratio. Therefore, the reduction of real interest rates is beneficial to the decline of M2/GDP ratio and financing cost.

In the case of China today, its M2/GDP ratios is too high; as to its financial structure, the proportion of the indirect financing is high while the indirect part is low and heavily reliable on equity financing. All this shows that China's financial market is still at a low level, the financialization of its economy is not full-grown and the monetization trend remains. In addition, the financial instruments representing modern trends of financial innovation lag behind the 
developed countries. At the same time, China's economic reform, transformation and upgrading bring about greater increase in demand for money; its quantitative expansion and speed dominated growth mode drives the expansion of money supply and the rapid rise of M2/GDP ratio. This in turn hinders the development of financial innovation and development, which should be the major issues to be addressed in adjusting and upgrading its financial structure.

China should further increase the proportion of its direct financing, upgrade the financing structure of its money market, and improve the efficiency and service quality of its banking and securities markets. With the further reform of its financial system, the M2/GDP ratio in China will show a downward trend in the long run due to the replacement of banking financing by other means and the diversification of its citizen's financial assets. To optimize its financial structure against the background of economic and financial globalization, China should make institutional, industrial and technological innovations, to absorb more private capital into the industry and to promote the development of small and medium-sized as well as mixed financial institutions; and it should accelerate the securitization of assets as well.

\section{Reference}

Allen, F., \& Gale, D. (2000). Comparing financial systems, Cambridge: MIT Press.

Beck, T., \& Levine, R. (2004). Stock Markets, Banks and Growth: Panel Evidence. Journal of Banking and Finance, 28(3), 423-442.

Field, A. J. (1984). Asset Exchanges and the Transactions Demand for Money, 74(3), 43-59.

Goldsmith, R. W. (1969). Financial structure and development. New Haven, Conn: Yale University Press.

Han, P., Li, B., \& Cui, Y. (2005). The M2/GDP Dynamic Growth, Money Supply and Policy Selection in China. Economic Research Journal china, 10, 37-47.

Huang, G., \& He, S. J. (2011). Abnormal Structure and the China's Currency: An Analysis from the Perspective of Financial Inhibitation in Economic Transition. Journal of Financial Research china,7, 1-13.

Jiang, C. (2004). Institutional Analysis of China s excess money, Journal of Guizhou University of Finance and Economics, 4, 32-21.

Li, B. (2004). Economic Development, Change in Structure and Disappearance of Money: With a Reexplanation of China Puzzle. Economic Research Journal china, 6, 24-32.

Liu, M. Z. (2001). China's M2/GDP(1980-2000). Trends, Stage and Its Determinants. Economic Research Journa lchina, 2, 3-12.

Mckinnon, R. (1973). Money and Capital in Economic Development,The Brookings Institution, Washington, D. C.

Milton, F., \& Schwartz, A. J. (1982). Monetary Trends in the United States and the United Kingdom:Their Relation to Income, Prices and Interest Rats, 1867- 1975, Chicago University Press, Chicago(for NBER).

Milton, F. (1988). Money and the Stock Market, Journal of Political Economy, 96(2), 221-245.

Qin, D. (2002). Household Savings in China: Its Determinants and Its Role in Quasi-Money Supply. China Economic Quarterly china, 2, 339-356

Shaw, E. (1973. Financial Deepening in Economic Development. Oxford University Press.

Wu , J. J. (2007). China's M2/GDP Is too High: An Analysis Based on IS-LM Model. Journal of Financial Research. China , 5, 40-48.

Xie, P. (1992). An Analysis of the Structure of China's Financial Assets. Economic Research Journal, 11, 30-37.

Xie, P., \& Zhang, H. Q. (2007). Structure of Financing, Non-performing Loans and M2/GDP. Economic Research Journal china, 2, 27-37

Yi Gang. (1996). An Analysis of the Structure of China's Financial Assets and Its Policy Meanings. Economic Research Journal china., 2, 26-33.

Yu, Y. D. (2002). The Dynamic Path of M2/GDP Increase. The Journal of World Economy china, 12, 3-13.

Zhang, J. (2006). An Insight into the High Level of China 'Monetarization. Economic Research Journal china, 6, 59- 69.

Zhao, L. Y., \& Wang, Y. M. (2005). Determinants of the Decline in Velocity of Money in China: A New Perspective. Social Sciences in China, 4, 17-28.

\section{$(\mathrm{cc})$ EY}

This work is licensed under a Creative Commons Attribution 3.0 License. 